\title{
KOMPONEN BIAYA DAN BIAYA SATUAN OPERASI \\ PENDIDIKAN TAMAN KANAK-KANAK (STUDI KASUS DI 3 TAMAN KANAK-KANAK)
}

\author{
Novy Chrystiana, Moch Alip \\ Budi Mulia Dua Foundation, Universitas Negeri Yogyakarta \\ novychrystiana@yahoo.com,moch_alip@uny.ac.id
}

\begin{abstract}
Abstrak
Penelitian ini bertujuan untuk mengetahui komponen biaya serta biaya satuan operasi pendidikan (BSOP) taman kanak-kanak (TK) di Depok, Sleman, Yogyakarta. Jenis penelitian ini adalah kualitatif deskriptif, data diambil purposive dari tiga TK di Depok, Sleman, Yogyakarta berdasarkan pertimbangan besarnya SPP dan program TK (half-day/ful-day). Dua TK yaitu A dan B adalah half-day dengan SPP dibawah Rp400.000,00 sedangkan C adalah TK full-day dengan SPP diatas Rp400.000,00. Pengumpulan data melalui deep interview dan kuesioner. Hasil penelitian ini adalah komponen biaya pada pendidikan TK: (1) biaya operasi personel berupa biaya gaji; (2) biaya operasi non personel berupa biaya (a) proses pendidikan, (b) kelembagaan, (c) administrasi sekolah, (d) komite sekolah, dan (e) perawatan dan perbaikan ringan. BSOP di TK half-day adalah Rp1.270.038,00/tahun/siswa dan Rp1.454.389,00/tahun/siswa, sedangkan BSOP di TK full-day adalah Rp10.466.134,00/ tahun/siswa. BSOP akan meningkat sejalan dengan (1) period time dan (2) rasio guru - siswa.
\end{abstract}

Kata kunci: taman kanak-kanak, komponen biaya, biaya satuan pendidikan

\section{COST COMPONENTS AND OPERATIONAL UNIT COSTS OF KINDERGARTEN EDUCATION (CASE STUDY AT THREE KINDERGARTENS)}

\begin{abstract}
This study aims to find out the cost components and operational unit costs of kindergarten educations in Depok, Sleman, Yogyakarta. This research was a descriptive qualitative study, data were collected purposively from three kindergartens in Depok, Sleman, Yogyakarta, in accordance to the amount of tuition fee and kindergarten program (half-day/full-day). Two kindergartens ( $A$ and $B$ ) are the halfday with tuition fee under Rp400.000,00, while C is full-day with tuition fee over than Rp400.000, 00. The data were collected through in-depth interviews and questionnaires. The results of the study show that cost components consist of: (1) the operational cost component for personnel in the form of salaries and (2) the operational cost component for non-personnel in the forms cost of: (a) educational process, (b) institutional, (c) school administration, (d) school committee, and (e) light maintenance and repair. The operational unit cost of the half-day kindergarten is Rp1.270.038,00/year/student and Rp1.454.389,00/year/student, while that of the full-day kindergarten is Rp10.466.134,00/year/ student. The operational unit cost will increase in line with (1) period time and (2) the teacher-student ratio.
\end{abstract}

Keywords: kindergartens, cost components, educational unit cost 


\section{Pendahuluan}

Pendidikan Anak Usia Dini (PAUD) merupakan upaya pembinaan yang ditujukan bagi anak sejak nol sampai dengan usia enam tahun (Undang-undang Nomor 20 Tahun 2003). Penyelenggaraan pendidikan untuk anak usia dini diselenggarakan dalam beberapa bentuk jalur pendidikan, seperti disebutkan dalam Permendiknas Nomor 58 Tahun 2009 bahwa Penyelenggaraan PAUD jalur pendidikan formal berbentuk Taman Kanak-Kanak (TK)/ Raudhatul Atfal (RA) dan bentuk lain yang sederajat, yang menggunakan program untuk anak usia $4-\leq 6$ tahun. PAUD jalur pendidikan nonformal berbentuk Taman Penitipan Anak (TPA) dan bentuk lain yang sederajat, yang menggunakan program untuk anak usia $0-<2$ tahun, $2-<4$ tahun, $4-\leq 6$ tahun dan Program Pengasuhan untuk anak usia 0 - $\leq 6$ tahun; Kelompok Bermain (KB) dan bentuk lain yang sederajat, menggunakan program untuk anak usia $2-<4$ tahun dan $4-\leq 6$ tahun.

Istilah Kindergarten atau Taman Kanak-kanak, menurut Morrison (1988, p.251) merupakan bagian penting bagi pendidikan bagi anak usia dini berusia tiga sampai dengan tujuh tahun sebelum anak memasuki pendidikan dasarnya. Pendidikan yang baik pada usia dini memberikan efek jangka panjang bagi peningkatan hasil akademik siswa, penurunan angka pengangguran dan mengurangi angka kejahatan (Barnett \& Ackerman, 2006, p.86). Dengan demikian pendidikan pada usia dini merupakan suatu tahap penting pendidikan yang tidak dapat diabaikan karena menentukan perkembangan dan keberhasilan anak. Wibowo (2012, p.47) menyatakan bahwa saat ini masyarakat juga sudah menyadari akan peran pentingnya pendidikan pada usia dini ini. Fenomena ini terjadi disebabkan beberapa hal, diantaranya karena kesibukan orang tua dalam mencari nafkah, akan tetapi menginginkan pendidikan yang baik dan bermutu dan banyaknya Sekolah Dasar yang mensyaratkan calon siswanya telah menyelesaikan pendidikan di TK.
Namun, Wiyani dan Barnawi (2012, p.27) menyatakan bahwa masih banyak juga para orang tua yang belum menyadari pentingnya pendidikan anak pada usia dini ini, terutama pada masyarakat di pedesan dan kalangan golongan ekonomi menengah ke bawah. Rendahnya animo ini karena masih banyak orang tua yang beranggapan masa sekolah adalah berawal di sekolah formal yaitu pada SD kelas 1 . Selain itu, besarnya biaya pendidikan untuk anak usia dini di Indonesia yang ditanggung oleh orang tua masih belum terjangkau oleh penduduk yang rata-rata kesejahteraannya masih rendah.

Kemendiknas (Balai Pusat Statistik) tahun 2012 tentang Rangkuman data TK tahun 2012-2013, melaporkan bahwa dari total 535 Taman Kanak-kanak yang ada di kabupaten Sleman, 69 TK diantaranya terdapat pada kecamatan Depok. Dari total 69 TK tersebut, satu TK yang diselenggarakan oleh pemerintah (TK Negeri), 61 TK swasta dan tujuh RA. Data tersebut memberikan gambaran bahwa 99,8\% TK diselenggarakan oleh swasta, sehingga hampir $100 \%$ biaya pendidikan di TK menjadi tanggung jawab orang tua anak didik dan yayasan penyelenggara.Besarnya biaya pendidikan pun menjadi beragam sesuai dengan tujuan penyelenggara pendidikan.

Biaya pendidikan menurut Supriadi (2010, p.4) berkenaan dengan semua jenis pengeluaran (cost) dalam penyelenggaraan pendidikan, baik dalam bentuk uang, barang maupun jasa (yang dapat dihargakan dengan uang). Untuk kepentingan analisis, biaya pendidikan diukur sebagai biaya satuan (unit cost), yaitu biaya pendidikan per tahun per siswa dan biaya siklus yaitu biaya yang dibutuhkan oleh setiap siswa untuk menyelesaikan suatu jenjang pendidikan (Ghozali, 2010, p.73). Juknis Penyelenggaraan Taman Kanak-kanak (Kemendikbud, 2013, p.49) menyebutkan bahwa pembiayaan pendidikan Taman Kanakkanak mencakup biaya investasi, biaya operasi dan biaya personal. Namun, dalam pernyataan tersebut belum dikemukakan besarnya biaya operasi, investasi, dan personal dalam penyelenggaraan pendidikan. 
Besar biaya operasi, investasi dan personal dapat dihitung oleh masingmasing penyelenggara pendidikan berdasarkan aktivitas yang dilakukan dalam program penyelenggaraan pendidikannya. Perhitungan biaya yang didasarkan pada aktivitas dikenal dengan sistem Activity Based Costing (ABC). Blocher et al. (2007, p.222) menyebutkan bahwa pendekatan perhitungan biaya aktivitas membebankan biaya sumber daya ke objek biaya berdasarkan aktivitas yang dilakukan objek biaya tersebut. Objek biaya pertama menurut Mulyadi $(2007$, p.8) adalah aktivitas yang mengkonsumsi sumber daya untuk menghasilkan produk/jasa. Informasi mengenai aktivitas pendidikan Taman Kanakkanak dapat diketahui menurut program penyelenggaraannya. Morrison (1988,p.262) menyebutkan bahwa program pendidikan Taman Kanak-kanak dapat dilaksanakan secara half-day dan full-day. Pada half-day program, siswa beraktivitas tiga jam sehari, bisa enam hari dalam seminggu atau hanya beberapa hari saja dalam seminggu, tergantung pada kebijakan penyelenggara sekolah. Sedangkan pada full-day program, siswa beraktivitas selama tujuh jam sehari, bisa beberapa hari dalam seminggu atau kombinasi beberapa hari dalam satu minggu.

Namun, informasi mengenai aktivitas-aktivitas yang memicu timbulnya biaya akibat proses penyelenggaraan pendidikannya belum disajikan dan diketahui oleh pengelola/penyelenggara pendidikan dalam perhitungan biaya pendidikan di sekolahnya. Observasi awal yang dilakukan oleh penulis menunjukkan bahwa sekolah menentukan besarnya biaya pendidikan berdasarkan pengeluaran (cost) dalam RAPBS. Keterbatasan kemampuan pihak sekolah dalam menyajikan informasi tentang sumber daya yang telah dikonsumsi oleh aktivitas sehingga menimbulkan biaya menyebabkan pengelolaan lembaga pendidikan tersebut kurang profesional yang akan mengakibatkan inefisiensi.

Pemerintah telah menetapkan Permendiknas nomor 58 tahun 2009 tentang Standar Pendidikan Anak Usia Dini, yang meliputi (1) Standar tingkat pencapaian perkembangan; (2) Standar pendidik dan tenaga kependidikan; (3) Standar isi, proses, dan penilaian; dan (4) Standar sarana dan prasarana, pengelolaan, dan pembiayaan, tetapi belum menetapkan standar biaya seperti yang telah ditetapkan dalam Permendiknas nomor 69 tahun 2009 tentang Standar biaya bagi pendidikan dasar dan menengah.

Penelitian ini didasarkan pada konsep dasar sistem ABC (Activity Based Costing) bahwa "cost is caused and cost can be managed" (biaya ada penyebabnya dan penyebab biaya dapat dikelola). Penyebab biaya adalah aktivitas, dan melalui penyediaan informasi lengkap tentang aktivitas kepada personel, personel akan dapat melakukan pengelolaan terhadap aktivitas secara efektif (Mulyadi, 2007, p.25). Biaya, dalam sistem ABC (Activity Based Costing) merupakan nilai rupiah sumber daya yang dikorbankan untuk melaksanakan aktivitas (Mulyadi, 2007, p.8). Aktivitas dalam sistem $A B C$ merupakan serangkaian peristiwa, kegiatan, dan tugas yang dilakukan dengan tujuan tertentu (Blocher et al., 2005, p.221; Hansen \& Mowen, 2000, p.328; dan Mulyadi, 2007, p.9).

Biaya dalam pendidikan adalah sejumlah nilai uang yang dibelanjakan atau jasa pelayanan yang diserahkan kepada siswa (Jones, 1985, p.3). Biaya pendidikan juga dapat diartikan sebagai sejumlah uang yang dibelanjakan oleh individu peserta didik, keluarga, masyarakat maupun pemerintah untuk berbagai keperluan penyelenggaraan pendidikan (Fattah, 2006, p.112; Suhardan, 2012, p.22; dan Supriadi, 2010: p.4). Sifat-sifat dalam biaya pendidikan tersebut menurut Supriadi (2003, p.5), Siregar (2003, p.7), Woodhall (2004, p.33) bisa merupakan (1) biaya langsung (direct cost) atau biaya tidak langsung (indirect cost), (2) biaya pribadi (private cost) atau biaya sosial (social cost) dan (3) biaya moneter (monetary cost) atau non moneter (non monetary cost). Biaya pendidikan, untuk keperluan analisis dinyatakan dalam biaya satuan pendidikan (unit cost), terdiri atas unit cost di orang tua anak didik yang terdiri atas biaya-biaya 
personal dan unit cost di penyelenggara pendidikan (sekolah) yang meliputi biaya operasi dan investasi (Ghozali, 2012, p.1 dan Kemendikbud, 2013, p.49).

Biaya operasi adalah biaya yang dikeluarkan untuk membiayai kegiatan operasional sekolah (Nurhadi, 2011, p.29). Biaya operasi terdiri atas (1) biaya operasi personel, yaitu biaya yang dikeluarkan untuk kesejahteraan dan pengembangan personel, dan (2) biaya operasi non personel, yaitu biaya yang dikeluarkan untuk penyediaan segala bahan, peralatan, perlengkapan, serta sarana prasarana yang digunakan untuk proses pembelajaran (Ghozali, 2010, p.74). Analisis biaya pendidikan operasi diukur dalam biaya satuan operasi pendidikan (operation/recurrent unit cost) yaitu total biaya operasi personel dan non personel per tahun per siswa.

Biaya investasi merupakan biaya yang ditimbulkan dari pengadaan sumber daya untuk penyelenggaraan pendidikan dan dimanfaatkan dalam waktu lebih dari satu tahun (Ghozali, 2010, p.96 dan Nurhadi, 2011, p.29). Biaya satuan investasi pendidikan (investment/capital/development unit cost) yaitu total biaya investasi per tahun per siswa.

Biaya personal adalah biaya yang dikeluarkan oleh orang tua anak didik untuk keperluan anak didik dalam mengikuti proses pembelajaran (Ghozali, 2010, p.79 dan Nurhadi: 2011, p.29). Biaya satuan personal (private unit cost) merupakan total biaya personal per tahun per siswa.

Biaya satuan pendidikan dihitung dengan menjumlahkan semua pengeluaran belanja pendidikan dalam satu tahun dan membaginya dengan jumlah siswa pada tahun tersebut (Coombs \& Hallak, 1987, p.17; Fattah, 2009, p.27; Ghozali, 2010, p.73).

Beberapa penelitian mengenai biaya pendidikan, lebih banyak dilakukan pada pendidikan dasar, menengah dan tinggi. Penelitian tersebut dapat dibagi menjadi beberapa kesimpulan, yaitu (1) Penelitian tentang pembiayaan pendidikan yang menghasilkan besaran biaya satuan pendidikan atau unit cost (Nanang Fatah,
2002), Dedi Supriadi (2003), dan Bappeda Bandung (2008), (2) Penelitian tentang pembiayaan pendidikan dan korelasinya dengan mutu, proses dan hasil belajar siswa (Nanang Fatah, 2002) dan (3) Penelitian tentang pembiayaan pendidikan yang meneliti komponen biaya apa saja yang seharusnya dibiayai dalam penyelenggaraan pendidikan untuk dapat mencapai mutu pendidikan yang diinginkan (Puslitbang, 2006). Namun, penelitian tentang biaya satuan pendidikan Taman Kanak-kanak (Unit cost) masih belum banyak dilakukan. Penelitian mengenai aktivitas dalam pendidikan TK yang mempengaruhi timbulnya biaya dan komponen biaya yang ditimbulkannya, juga belum banyak dilakukan.

Atas dasar pernyataan diatas, maka penelitian ini dilakukan untuk menjawab pertanyaan sebagai berikut: (1) Aktivitas apa saja yang dapat menimbulkan biaya dalam pendidikan TK? (2) Komponen biaya apa saja yang terjadi dalam pendidikan TK? (3) Berapa besarnya biaya satuan operasi (BSOP) TK?

\section{Metode Penelitian}

Penelitian ini menggunakan metode kualitatif deskriptif. Data diambil secara purposive pada tiga TK di Kecamatan Depok, Kabupaten Sleman, Yogyakarta dengan pertimbangan: (1) penyelenggaraan TK (half-day atau full-day), (2) besarnya SPP yang harus dibayarkan oleh orang tua peserta didik.

Kemendiknas tahun 2012-2013 (Badan Pusat Statistik) tentang Rangkuman data TK, melaporkan besaran SPP TK di Kecamatan Depok, Kabupaten Sleman, Yogyakarta sebagai berikut:

Tabel 1. Data SPP TK Kecamatan Depok, Kabupaten Sleman, Yogyakarta

\begin{tabular}{clc}
\hline No. & \multicolumn{1}{c}{ SPP/bulan/siswa } & $\begin{array}{c}\text { Jumlah } \\
\text { sekolah }\end{array}$ \\
\hline 1. & $<$ Rp100.000,00 & 40 \\
2. & Rp100.000,00 - Rp200.000,00 & 13 \\
3. & Rp201.000,00 - Rp400.000,00 & 6 \\
4. & $>$ Rp400.000,00 & 2 \\
5. & Data tidak valid & 8 \\
\hline & Total jumlah sekolah & 69 \\
\hline
\end{tabular}


Observasi awal oleh peneliti menghasilkan data bahwa dari total 69 TK, 66 TK diselenggarakan secara half-day dan 3 TK adalah full-day. Dengan demikian ditentukan tiga TK berdasarkan besaran SPP dan penyelenggaraan pendidikan sebagai berikut: (1) TK A (TK half-day) dengan jumlah siswa 55, SPP/bulan/siswa Rp90.000,00; (2) TK B (TK half-day) dengan jumlah siswa 157, SPP/bulan/siswa Rp150.000,00; (3) TK C (TK full-day) dengan jumlah siswa 122, SPP/bulan/siswa Rp$520.000,00$.

Subyek penelitian adalah Kepala sekolah, guru, staf administrasi/bendahara sekolah dan pengurus yayasan.

Teknik pengumpulan data dilakukan secara triangulasi yaitu wawancara mendalam, observasi pasif dan studi dokumentasi. Instumen peneltian adalah peneliti sendiri, dengan melakukan wawancara mendalam, observasi dan studi dokumentasi, melakukan analisis terhadap data yang ditemukan dan selanjutnya menarik kesimpulan.

\section{Teknik Analisis Data}

Analisis data dilakukan dalam dua tahap, yaitu:

\section{Identifikasi aktivitas-aktivitas dalam proses pendidikan TK.}

Sistem ABC (Activity Based Costing) menjadi dasar pemikiran identifikasi aktivitas yang terjadi di TK, dan dilakukan melalui wawancara mendalam kepada subyek penelitian dengan mengajukan pertanyaan utama: (a) apa saja kegiatan/ aktvitas yang anda lakukan di sekolah?; (b) berapa lama waktu yang dibutuhkan untuk melaksanakan aktivitas tersebut?

Analisis komponen biaya dengan menggunakan sistem $A B C$ sebagai dasar pemikiran.

Analisis dilakukan dengan empat cara: (a) mengumpulkan data mengenai laporan biaya pengeluaran sekolah. Biaya yang tercantum dalam laporan keuangan sekolah, dikelompokkan terlebih dahulu dalam kategori: (1) biaya operasi, (2) biaya investasi dan (3) biaya personal. Biayabiaya yang diperhitungkan hanyalah biaya operasi saja, baik biaya operasi personel maupun non personel. Biaya investasi dan personal tidak ikut diperhitungkan dalam perhitungan BSOP.; (b) menghitung biaya operasi personel dengan terlebih dahulu merinci jenis personel yaitu Kepala sekolah, guru tetap/ guru yayasan, guru tidak tetap, guru ekstra, dan support staf yang ada (staf administrasi, staf keamanan dan staf kebersihan). Biaya operasi personel dihitung dengan merinci kedalam sub komponen biaya gaji, tunjangan jabatan, Tunjangan Hari raya dan asuransi kesehatan. Satuan waktu dalam perhitungan biaya operasi personel disamakan dalam satu satuan waktu yaitu biaya dalam satu tahun. (c) menghitung biaya operasi non personel dengan terlebih dahulu merinci biaya-biaya yang terjadi dalam proses pendidikan diluar biaya gaji. Biaya yang sama dikelompokkan menjadi satu kategori komponen biaya, sub kategori komponen biaya dan dihitung dalam satuan waktu yang sama yaitu biaya dalam satu tahun. Biaya yang diperhitungkan dalam perhitungan hanya biaya operasi, biaya personal dan biaya investasi yang turut muncul akibat dari aktivitas tidak ikut diperhitungkan dalam perhitungan biaya; (d) menghitung biaya satuan operasi pendidikan (BSOP) dengan menjumlah biaya operasi personel dan non personel dalam satu tahun dan dibagi dengan total jumlah siswa yang bersekolah pada tahun ajaran tersebut.

\section{Hasil Penelitian dan Pembahasan}

Wawancara dan observasi menghasilkan data aktivitas sebagai berikut: 
Tabel 2. Aktivitas di TK A- TK B- TK C (half-day dan full-day)

\begin{tabular}{|c|c|c|c|c|c|}
\hline No. & Pelaku & Aktivitas & TKA & TK B & TK C \\
\hline \multirow[t]{6}{*}{1} & Siswa & Proses Pendidikan siswa & & & \\
\hline & & 1.1. kegiatan intra & $\square$ & $\nabla$ & $\nabla$ \\
\hline & & 1.2. kegiatan ekstra & $\square$ & $\nabla$ & $\square$ \\
\hline & & 1.3. pembinaan siswa & $\bar{\nabla}$ & $\bar{\nabla}$ & $\bar{\nabla}$ \\
\hline & & 1.4. UKS & $\bar{\square}$ & $\bar{\nabla}$ & $\bar{\nabla}$ \\
\hline & & 1.5. pengasuhan (child care) & - & - & $\square$ \\
\hline \multirow[t]{9}{*}{2} & Guru & 2.1. kelembagaan & & & \\
\hline & & a. Rapat-rapat & $\square$ & $\square$ & $\nabla$ \\
\hline & & Proses pendidikan & & & \\
\hline & & $\begin{array}{l}\text { 2.2. proses pendidikan siswa } \\
\text { a. Persoapan materi } \\
\text { b. Materi inti } \\
\text { c. penutup }\end{array}$ & $\square$ & $\square$ & $\nabla$ \\
\hline & & 2.3. penilaian siswa & $\nabla$ & $\nabla$ & $\nabla$ \\
\hline & & 2.4. Administrasi keuangan dan kesekretariatan & $\square$ & - & - \\
\hline & & 2.5. Lain-lain (pendampingan) & $\square$ & $\nabla$ & $\square$ \\
\hline & & 2.6. Child care & - & - & $\square$ \\
\hline & & 2.7. Promosi sekolah & $\square$ & $\square$ & $\square$ \\
\hline \multirow[t]{2}{*}{3} & Staf adm & Administrasi & & & \\
\hline & & 3.1. tugas administarsi sekolah & - & $\square$ & $\square$ \\
\hline 4 & Staf Keuangan & 4.1. administrasi keuangan sekolah & - & $\square$ & $\square$ \\
\hline 5 & Staf kebersihan & 5.1. menjaga kebersihan sekolah & $\square$ & $\square$ & $\square$ \\
\hline 6 & Staf keamanan & 6.1. menjaga keamanan sekolah & - & - & $\square$ \\
\hline & Komite sekolah & 7.1. Pertemuan berkala & $\square$ & $\nabla$ & $\square$ \\
\hline & & 7.2. Komite drumband & - & $\nabla$ & - \\
\hline & & $\begin{array}{l}\text { 7.3. Acara pendukung promosi sekolah (flea market, } \\
\text { Sunday morning, parents volunteers) }\end{array}$ & - & - & च \\
\hline & & 7.4. Penyediaan konsumsi taman gizi & $\nabla$ & $\nabla$ & $\overline{-}$ \\
\hline & & 7.5. Acara tutup tahun & $\square$ & $\nabla$ & $\nabla$ \\
\hline
\end{tabular}

Tabel 3. Komponen Biaya Operasi Personel

\begin{tabular}{|c|c|c|c|c|}
\hline BIAYA & KOMPONEN BIAYA & $\begin{array}{l}\text { TKA } \\
\text { (Rp.) }\end{array}$ & $\begin{array}{l}\text { TK B } \\
\text { (Rp.) }\end{array}$ & $\begin{array}{l}\text { TK C } \\
\text { (Rp.) }\end{array}$ \\
\hline Gaji Guru & $\begin{array}{l}\text { Gaji Pengurus yayasan/Kep.Sek. } \\
\text { a. Gaji pokok } \\
\text { b. Tunjangan jabatan } \\
\text { c. THR } \\
\text { d. Dana Sosial/ASKES } \\
\text { Gaji Pendidik (Guru tetap) } \\
\text { a. Gaji pokok } \\
\text { b. Tunjangan jabatan } \\
\text { c. THR } \\
\text { d. Dana Sosial/ASKES } \\
\text { Gaji Pendidik (Guru tidak tetap) } \\
\text { a. Gaji pokok } \\
\text { b. Tunjangan jabatan } \\
\text { c. THR } \\
\text { d. Dana Sosial/ASKES } \\
\text { Gaji Pendidik (Guru ekstra) } \\
\text { a. Gaji pokok } \\
\text { b. Tunjangan jabatan } \\
\text { c. THR } \\
\text { d. Dana Sosial/ASKES } \\
\text { Gaji Pendidik (PNS) } \\
\text { a. Gaji pokok } \\
\text { b. Tunjangan jabatan } \\
\text { c. THR } \\
\text { d. Dana Sosial/ASKES }\end{array}$ & $\begin{array}{c}25,500,000 \\
- \\
1,000,000 \\
- \\
\\
- \\
- \\
- \\
- \\
\\
5,280,000 \\
- \\
- \\
-\end{array}$ & $\begin{array}{c}30,300,000 \\
- \\
- \\
- \\
\\
28,800,000 \\
- \\
600,000 \\
7,200,000\end{array}$ & $\begin{array}{r}117,000,000 \\
36,000,000 \\
12,000,000 \\
17,640,000 \\
\\
331,500,000 \\
- \\
25,500,000 \\
43,860,000\end{array}$ \\
\hline Gaji staf Adm & $\begin{array}{l}\text { Gaji staf } \\
\text { a. Gaji pokok } \\
\text { b. Tunjangan jabatan } \\
\text { c. THR } \\
\text { d. Dana Sosial/ASKES }\end{array}$ & $\begin{array}{l}- \\
- \\
- \\
-\end{array}$ & $\begin{array}{c}2,400,000 \\
- \\
600,000 \\
-\end{array}$ & $\begin{array}{c}20,800,000 \\
- \\
1,600,000 \\
5,160,000 \\
\end{array}$ \\
\hline $\begin{array}{l}\text { Gaji staf } \\
\text { kebersihan }\end{array}$ & $\begin{array}{l}\text { a. Gaji pokok } \\
\text { b. Tunjangan jabatan } \\
\text { c. THR } \\
\text { d. Dana Sosial/ASKES }\end{array}$ & $\begin{array}{l}3,000,000 \\
- \\
200,000 \\
-\end{array}$ & $\begin{array}{c}2,400,000 \\
- \\
600,000 \\
-\end{array}$ & $\begin{array}{l}69,720,000 \\
- \\
5,850,000 \\
-\end{array}$ \\
\hline $\begin{array}{l}\text { Gaji staf } \\
\text { keamanan }\end{array}$ & $\begin{array}{l}\text { a. Gaji pokok } \\
\text { b. Tunjangan (Uang hadir,lembur } \\
\text { tetap, dan fee outsourching) } \\
\text { c. THR } \\
\text { d. Dana sosial (Astek) } \\
\end{array}$ & $\begin{array}{l}- \\
- \\
- \\
-\end{array}$ & $\begin{array}{l}- \\
- \\
- \\
-\end{array}$ & $\begin{array}{r}38,400,000 \\
17,088,960 \\
3,200,000 \\
1,877,760 \\
\end{array}$ \\
\hline \multicolumn{2}{|c|}{ Total Biaya Operasi Personel } & $34,980,000$ & $147,617,000$ & $843,996,720$ \\
\hline
\end{tabular}


Tabel 4. Komponen Biaya Operasi non Personel

\begin{tabular}{|c|c|c|c|c|}
\hline BIAYA & KOMPONEN BIAYA & $\begin{array}{l}\text { TK A } \\
\text { (Rp.) }\end{array}$ & $\begin{array}{l}\text { TK B } \\
\text { (Rp.) }\end{array}$ & $\begin{array}{l}\text { TK C } \\
\text { (Rp.) }\end{array}$ \\
\hline Proses pendidikan & $\begin{array}{l}\text { Biaya Proses Pendidikan } \\
\text { a. Kegiatan ekstra } \\
\text { b. Kegiatan intra } \\
\text { c. Pembinaan siswa } \\
\text { d. UKS } \\
\text { e. LKA } \\
\text { f. Buku Administrasi siswa } \\
\text { Biaya kelembagaan guru } \\
\text { a. Rapat-rapat } \\
\text { b. Iuran kelembagaan }\end{array}$ & $\begin{array}{c}- \\
6,796,800 \\
5,184,000 \\
- \\
5,500,000 \\
2,357,100 \\
\\
\\
- \\
1,200,000 \\
\end{array}$ & $\begin{array}{r}18,000,000 \\
37,100,000 \\
8,084,000 \\
- \\
- \\
- \\
\\
1,350,000 \\
1,200,000 \\
\end{array}$ & $\begin{array}{r}53,642,188 \\
144,833,796 \\
19,977,221 \\
8,629,558 \\
35,509,355 \\
2,425,000\end{array}$ \\
\hline & sub total & $21,037,900$ & $65,734,000$ & $269,518,507$ \\
\hline $\begin{array}{l}\text { Administrasi/ } \\
\text { overhead kantor }\end{array}$ & $\begin{array}{l}\text { Biaya Administrasi Sekolah } \\
\text { a. Biaya Rapat } \\
\text { b. ATK } \\
\text { c. BHP } \\
\text { d. Transportasi } \\
\text { e. Fotocopy } \\
\text { f. Publikasi } \\
\text { g. Lain-lain } \\
\end{array}$ & $\begin{array}{l}- \\
582,000 \\
- \\
- \\
- \\
- \\
744,000\end{array}$ & $\begin{array}{l}- \\
1,800,000 \\
- \\
- \\
1,200,000 \\
- \\
- \\
\end{array}$ & $\begin{array}{r}5,280,494 \\
8,523,534 \\
14,573,239 \\
10,560,988 \\
4,457,986 \\
9,199,220 \\
5,904,791 \\
\end{array}$ \\
\hline & sub total & $\mathbf{1 , 3 2 6 , 0 0 0}$ & $3,000,000$ & $58,500,252$ \\
\hline Komite sekolah & Biaya Konsumsi & 4,71 & 4,800 & $7,750,000$ \\
\hline $\begin{array}{l}\text { Perbaikan dan } \\
\text { perawatan }\end{array}$ & $\begin{array}{l}\text { PERBAIKAN DAN PERAWATAN } \\
\text { a. Biaya alat dan bahan kebersihan } \\
\text { b. Pemeliharaan/perbaikan } \\
\text { gedung dan halaman } \\
\text { c. Pemeliharaan alat pembelajaran } \\
\text { d. Perawatan kendaraan dinas } \\
\text { DAYA DAN JASA } \\
\text { a. Listrik dan air } \\
\text { b. Gas } \\
\text { c. Internet } \\
\text { d. Telepon } \\
\text { e. Majalah/koran } \\
\text { f. Restribusi sampah }\end{array}$ & $\begin{array}{l}1,836,000 \\
5,238,000 \\
- \\
- \\
480,000 \\
- \\
- \\
- \\
- \\
240,000 \\
\end{array}$ & $\begin{array}{l}2,448,000 \\
2,040,000 \\
- \\
- \\
2,100,000 \\
- \\
- \\
- \\
- \\
600,000 \\
\end{array}$ & $\begin{array}{r}12,201,520 \\
31,308,587 \\
12,189,381 \\
10,500,000 \\
5,584,824 \\
1,300,000 \\
3,520,000 \\
2,785,211 \\
1,500,000 \\
2,100,000 \\
\end{array}$ \\
\hline & sub total & $7,794,000$ & $7,188,000$ & $82,989,523$ \\
\hline \multicolumn{2}{|c|}{ Total Biaya Operasi non personel } & $34,872,100$ & $80,722,000$ & $418,758,282$ \\
\hline
\end{tabular}

Tabel 5. Biaya Personal yang Diselenggarakan Oleh Sekolah

\begin{tabular}{|c|c|c|c|c|}
\hline BIAYA & KOMPONEN BIAYA & $\begin{array}{l}\text { TKA } \\
\text { (Rp.) }\end{array}$ & $\begin{array}{l}\text { TK B B } \\
\text { (Rp.) }\end{array}$ & $\begin{array}{l}\text { TK C } \\
\text { (Rp.) }\end{array}$ \\
\hline $\begin{array}{l}\text { 2. Seragam } \\
\text { 3. ATS } \\
\text { 4. Konsumsi } \\
\text { guru dan staf }\end{array}$ & $\begin{array}{l}\text { 1. Biaya Konsumsi Siswa } \\
\text { 1.1. Snack siswa } \\
\text { 1.2. Snack dan makan siang siswa } \\
\text { 1.3. Taman Gizi } \\
\text { 2. Seragam siswa } \\
\text { 3. ATS } \\
\text { 4. Biaya Konsumsi Guru dan staf } \\
\text { 4.1. air minum }\end{array}$ & $\begin{array}{c}12,960,000 \\
- \\
7,776,000 \\
2,160,000 \\
5,238,000 \\
- \\
-\end{array}$ & $\begin{array}{c}- \\
- \\
20,400,000 \\
37,500,000 \\
20,400,000 \\
- \\
-\end{array}$ & $\begin{array}{c}- \\
208,348,650 \\
- \\
14,493,000 \\
32,072,052 \\
60,271,761 \\
16,797,400\end{array}$ \\
\hline & total biaya personal & $28,134,000$ & $78,300,000$ & $\mathbf{3 3 1 , 9 8 2 , 8 6 3}$ \\
\hline
\end{tabular}

Tabel 6. Total Biaya Operasi

\begin{tabular}{|c|c|c|c|c|c|c|c|c|c|c|}
\hline No & KOMPONEN BIAYA & $\begin{array}{l}\text { TKA } \\
\text { (Rp.) }\end{array}$ & \begin{tabular}{|c|}
$\%$ \\
+ personal
\end{tabular} & $\begin{array}{c}\% \\
\text {-personal }\end{array}$ & $\begin{array}{c}\text { TK B } \\
\text { (Rp.) }\end{array}$ & \begin{tabular}{|c|}
$\%$ \\
+ personal
\end{tabular} & \begin{tabular}{|c|}
$\%$ \\
-personal
\end{tabular} & $\begin{array}{l}\text { TK C } \\
\text { (Rp.) }\end{array}$ & \begin{tabular}{|c|}
$\%$ \\
+ personal
\end{tabular} & $\begin{array}{c}\% \\
\text {-personal }\end{array}$ \\
\hline 1 & Biaya Operasi Personel & $34,980,000$ & $35.70 \%$ & $50.08 \%$ & $147,617,000$ & $48.14 \%$ & $64.65 \%$ & $843,996,720$ & $52.9 \%$ & $66.8 \%$ \\
\hline 2 & Biaya Operasi non Personel & $34,872,100$ & $35.59 \%$ & $49.92 \%$ & $80,722,000$ & $26.32 \%$ & $35.35 \%$ & $418,758,282$ & $26.3 \%$ & $33.2 \%$ \\
\hline 3 & Biaya Personal & $28,134,000$ & $28.71 \%$ & & $78,300,000$ & $25.53 \%$ & & $331,982,863$ & $20.8 \%$ & - \\
\hline \multicolumn{2}{|r|}{ total biaya operasi pendidikan } & $97,986,100$ & $100.00 \%$ & $100.00 \%$ & $306,639,000$ & $100 \%$ & $100 \%$ & $1,594,737,865$ & $100 \%$ & $100 \%$ \\
\hline \multicolumn{2}{|r|}{ total biaya tanpa biaya personal } & $69,852,100$ & & & $228,339,000$ & & & $1,262,755,002$ & & \\
\hline \multicolumn{2}{|c|}{ Biaya Satuan Operasi Pendidikan } & $1,270,038.18$ & & & $1,454,388.54$ & & & $10,350,450.84$ & & \\
\hline
\end{tabular}




\section{Pembahasan}

Aktivitas-aktivitas yang terjadi pada TK A dan TK B (sebagai TK half-day) hampir sama dengan TK C sebagai TK fullday. Perbedaannya pada TK C sebagai TK full-day terdapat aktivitas child care. Aktivitas yang terjadi dalam penyelenggaraan pendidikan TK dan biaya yang ditimbulkannya adalah sebagai berikut:

Pertama, aktivitas proses pendidikan, memicu timbulnya: (a) biaya operasi personel berupa biaya gaji dan tunjangan yang melekat, (b) biaya operasi non personel, berupa biaya kegiatan intra, ekstra, pembinaan siswa, UKS, LKA, dan buku administrasi siswa. Biaya ini merupakan konsekuensi dari aktivitas siswa pada proses pendidikan. Konsekuensi aktivitas proses pendidikan pada guru adalah biaya kelembagaan berupa biaya rapat-rapat baik intern maupun kelembagaan. Biaya yang turut muncul dalam aktivitas proses pendidikan adalah munculnya biaya personal berupa biaya konsumsi siswa, biaya ATS dan biaya seragam siswa. Biaya-biaya ini tidak turut diperhitungkan dalam perhitungan BSOP.

Jika dilihat dari prosentase total biaya operasi, maka dapat dianalisa bahwa biaya personel memiliki prosentase ratarata $50 \%$, bahkan pada TK C yang merupakan TK full-day biaya personel mencapai $66,8 \%$. Hal ini sejalan dengan rasio guru dan siswa yaitu TK A 1: 22, TK B 1: 12 dan TK C 1: 6. Rasio guru merupakan salah satu faktor yang menentukan besarnya biaya pendidikan di Taman kanak-kanak (Levin \& schwartz, 2006: p.6).

Biaya personal, juga memiliki nilai yang cukup signifikan yaitu $28 \%$ (TK A), $25 \%$ (TK B) dan 20\% (TK C) dari total biaya operasi jika turut dihitung dalam BSOP. Biaya ini selalu muncul sebagai perhitungan biaya operasi di TK sebagai konsekuensi dari penyediaan fasilitas nutrisi bagi anak didik berupa penyediaan komsumsi siswa (Levin \& Schwartz, 2006: p.10). Namun, dalam perhitungan BSOP biaya personal ini tidak dipehitungkan.

Kedua, aktivitas kelembagaan guru, menimbulkan biaya operasi non personel yaitu biaya rapat dan iuran kelembagaan. Biaya ini kadang dikategorikan sebagai biaya operasi kantor/ overhead kantor, sehingga pada TK $\mathrm{C}$ tidak tercantum besaran biaya kelembagaan tersebut.

Ketiga, aktivitas administrasi sekolah, pada TK B dan TK C menimbulkan: (a) biaya operasi personel berupa gaji staf adminitrasi. Aktivitas administrasi sekolah pada TK A dilakukan oleh guru sendiri sehingga tidak ada biaya operasi personel staf administrasi. (b) biaya operasi non personel berupa biaya overhead kantor. Pada TK A dan TK B tidak secara spesifik memisahkan biaya BHP dengan ATK sehingga biaya yang muncul hanyalah biaya fotocopy dan ATK (yang juga masuk didalamnya biaya BHP). Biaya Publikasi tidak turut diperhitungkan oleh TK A dan TK B karena tidak secara spesifik memperhitungkan biaya publikasi. Aktivitas administrasi sekolah juga memunculkan biaya personal pada TK C berupa biaya konsumsi staf. Biaya ini muncul sejalan dengan lamanya jam sekolah siswa (periode time) sehingga sekolah harus membiayai kebutuhan personal bagi staf dan guru. Biaya personal ini tidak turut diperhitungkan dapam perhitungan BSOP.

Keempat, aktivitas komite sekolah. Biaya yang dihitung dalam aktivitas Komite Sekolah ini hanyalah biaya konsumsi pertemuan rutin yang diselenggarakan oleh sekolah, yang merupakan biaya operasi non personel. Biaya personal yang terjadi akibat aktivitas Komite Sekolah tidak turut dihitung dalam perhitungan BSOP. Misal biaya konsumsi yang diadakan sendiri oleh wali siswa pada aktivitas taman gizi, tidak diperhitungkan dalam BSOP.

Kelima, aktivitas perbaikan dan perawatan ringan, menimbulkan konsekuensi (a) biaya operasi personel, berupa gaji staf Rumah Tangga/umum atau gaji petugas keamanan. Biaya gaji petugas keamanan yang terjadi pada TK C, merupakan konsekuensi dari rasio lahan sekolah dengan siswa. (b) biaya operasi non personel, berupa penyediaan alat dan bahan serta biaya daya dan jasa. Besarnya prosentasi biaya perawatan dan biaya dan jasa juga 
merupakan konsekuensi rasio lahan sekolah dan siswa. Biaya personal yang terjadi pada aktivitas ini, yaitu biaya konsumsi staf tidak ikut diperhitungkan dalam perhitungan BSOP.

\section{Simpulan dan saran}

\section{Simpulan}

Aktivitas dalam penyelenggaraan TK yang memicu timbulnya biaya adalah aktivitas: (a) proses pendidikan siswa, (b) kelembagaan, (c) administrasi sekolah, (d) perawatan dan perbaikan ringan dan (e) komite sekolah. Perbedaan aktivitas antara TK half-day dengan full-day terletak pada adanya aktivitas pengasuhan (child care) dalam penyelenggaraan TK full-day.

Aktivitas dan komponen biaya yang terjadi pada penyelenggaraan TK:

Tabel 7. Aktivitas dan Komponen Biaya Taman Kanak-kanak

\begin{tabular}{|c|c|c|c|c|c|}
\hline No & Aktivitas & Komponen Biaya & TK & $\begin{array}{l}\text { Biaya } \\
\text { (Rp). }\end{array}$ & $\begin{array}{c}\% \\
\text { Biaya }\end{array}$ \\
\hline \multirow[t]{6}{*}{1} & \multirow{6}{*}{$\begin{array}{l}\text { Proses } \\
\text { pendidikan } \\
\text { siswa }\end{array}$} & Biaya Operasi Personel & TK A & $31,780,000$ & $32.4 \%$ \\
\hline & & \multirow[t]{2}{*}{ Biaya Operasi non personel } & TK B & $141,617,000$ & $46.2 \%$ \\
\hline & & & TKC & $680,300,000$ & $42.7 \%$ \\
\hline & & \multirow{3}{*}{ Biaya Operasi non personel } & TK A & $19,837,900$ & $20.2 \%$ \\
\hline & & & TK B & $63,184,000$ & $20.6 \%$ \\
\hline & & & TKC & $265,017,118$ & $16.6 \%$ \\
\hline \multirow[t]{6}{*}{2} & \multirow[t]{6}{*}{ Kelembagaan } & \multirow[t]{3}{*}{ Biaya Operasi Personel } & TK A & - & - \\
\hline & & & TK B & - & - \\
\hline & & & TKC & - & - \\
\hline & & \multirow[t]{3}{*}{ Biaya Operasi non personel } & TK A & $1,200,000$ & $1.2 \%$ \\
\hline & & & TK B & $2,550,000$ & $0.8 \%$ \\
\hline & & & TKC & $4,501,389$ & $0.3 \%$ \\
\hline \multirow[t]{6}{*}{3} & \multirow{6}{*}{$\begin{array}{l}\text { Administrasi } \\
\text { sekolah }\end{array}$} & \multirow[t]{3}{*}{ Biaya Operasi Personel } & TK A & - & - \\
\hline & & & TK B & $3,000,000$ & $1.0 \%$ \\
\hline & & & TKC & $27,560,000$ & $1.7 \%$ \\
\hline & & \multirow[t]{3}{*}{ Biaya Operasi non personel } & TK A & $1,326,000$ & $1.4 \%$ \\
\hline & & & TK B & $3,000,000$ & $1.0 \%$ \\
\hline & & & TKC & $58,500,252$ & $3.7 \%$ \\
\hline \multirow[t]{6}{*}{4} & \multirow{6}{*}{$\begin{array}{l}\text { Perawatan } \\
\text { perbaikan } \\
\text { ringan }\end{array}$} & \multirow[t]{3}{*}{ Biaya Operasi Personel } & TK A & $3,200,000$ & $3.3 \%$ \\
\hline & & & TK B & $3,000,000$ & $1.0 \%$ \\
\hline & & & TKC & $136,136,720$ & $8.5 \%$ \\
\hline & & \multirow[t]{3}{*}{ Biaya Operasi non personel } & TK A & $7,794,000$ & $8.0 \%$ \\
\hline & & & TK B & $7,188,000$ & $2.3 \%$ \\
\hline & & & TKC & $82,989,523$ & $5.2 \%$ \\
\hline \multirow[t]{6}{*}{5} & \multirow{6}{*}{ Komite sekolah } & \multirow{3}{*}{ Biaya Operasi Personel } & TK A & - & - \\
\hline & & & TK B & - & - \\
\hline & & & TKC & - & - \\
\hline & & \multirow[t]{3}{*}{ Biaya Operasi non personel } & TK A & $4,714,200$ & $4.8 \%$ \\
\hline & & & TK B & $4,800,000$ & $1.6 \%$ \\
\hline & & & TKC & $7,750,000$ & $0.5 \%$ \\
\hline \multirow[t]{3}{*}{6} & \multirow[t]{3}{*}{ - } & \multirow[t]{3}{*}{ Biaya Personal } & TK A & $28,134,000$ & $28.7 \%$ \\
\hline & & & TK B & $78,300,000$ & $25.5 \%$ \\
\hline & & & TKC & $331,982,863$ & $20.8 \%$ \\
\hline
\end{tabular}

Biaya satuan operasi pendidikan (BSOP). Biaya satuan operasi pendidikan
(BSOP) pada TK A (half-day), TK B (halfday) dan TK C (full-day) adalah:

Tabel 8. BSOP Taman Kanak-kanak

\begin{tabular}{|c|c|l|r}
\hline No & Sekolah & \multicolumn{1}{|c}{ Komponen Biaya } & \multicolumn{1}{|c}{ Jumlah } \\
\hline \multirow{2}{*}{1} & \multirow{2}{*}{ TK A } & & (Rp.) \\
& & Total biaya operasi personel & $34,980,000$ \\
& & Total biaya operasi non personel & $34,872,100$ \\
& & Total biaya operasi pendidikan & $69,852,100$ \\
& & Biaya Satuan Operasi Pendidikan/tahun/siswa & $\mathbf{1 , 2 7 0 , 0 3 8}$ \\
\hline \multirow{2}{*}{2} & \multirow{2}{*}{ TK B } & Total biaya operasi personel & $147,617,000$ \\
& & Total biaya operasi non personel & $80,722,000$ \\
& & Total biaya operasi pendidikan & $228,339,000$ \\
& & Biaya Satuan Operasi Pendidikan/tahun/siswa & $\mathbf{1 , 4 5 4 , 3 8 9}$ \\
\hline \multirow{2}{*}{3} & \multirow{2}{*}{ TK C } & Total biaya operasi personel & $843,996,720$ \\
& & Total biaya operasi non personel & $418,758,282$ \\
& & Total biaya operasi pendidikan & $1,262,755,002$ \\
& & Biaya Satuan Operasi Pendidikan/tahun/siswa & $\mathbf{1 0 , 3 5 0 , 4 5 1}$ \\
& & & \\
\hline
\end{tabular}


Saran

Perhitungan BSOP masih bersifat subjektif (berdasarkan laporan Kepala Sekolah). Masih terdapat beberapa Komponen yang diabaikan oleh Pengelola/Kepala sekolah dalam perhitungan Biaya Operasinya.

Perlunya penelitian lebih lanjut tentang biaya satuan pendidikan (unit cost) Taman Kanak-kanak yang turut menghitung biaya investasi dan biaya personal dalam perhitungan biaya satuan pendidikan total.

Berdasarkan hasil penelitian diketahui bahwa terdapat perbedaan yang cukup besar pada biaya personel sejalan dengan rasio guru dan siswa, maka perlu penelitian lebih lanjut bagaimana pengaruh rasio guru dan siswa tersebut terhadap mutu pendidikan yang dihasilkannya.

Pentingnya jumlah siswa yang bersekolah (enrollment) agar BSOP-nya semakin kecil, sehingga dibutukan dana promosi dalam setiap RAPBS.

\section{Daftar Pustaka}

Abbot, M.S., et al. (2011). Pendekatanpendekatan alternatif pendidikan anak usia dini (paud). (Terjemahan Imam Chourmain). Georgia: Humanics Ltd Partners. (Buku asli diterbitkan tahun 1976)

Bappeda Bandung. (2008). Analisa budget mapping pendidikan di kota bandung. Bandung: Pemerintah Daerah Kabupaten Bandung.

Barnett, S.W. \& Ackerman, D.J. (2006), Costs, benefits, and long-term effects of early care and education programs: recommendations and cautions for community developers. Community development: journal of the community development society, vol. 37, no. 2

Blocher,E.J. et al. (2007). Manajemen biaya, penekanan strategis. (terjemahan Penerbit Salemba Empat). The Mc grawhill companies. (buku asli diterbitkan tahun 2005)
Cardos, I.R. \& Pete, S. (2011). Activitybased costing $(\mathrm{ABC})$ and activitybased management (ABM) implementation- is this the solution for organizations to gain profitability? Romanian Journal of Economics, vol. 32, issue 1(41). Diambil pada tanggal 23 Desember 2013, dari http://focusintl.com/ RBM104-2011-1-9.pdf

Chapman, M. (2011). The british columbia: full day kindergarten program guide. Canada: GT. Publishing services Ltd. Diambil pada tanggal 23 desember 2013, dari http:// bced.gov.bc.ca.pdf/full-daykindergarten-program-guide

Chourmain, I. (2011). Pendekatan alternatifalternatif pendidikan anak usia dini. Jakarta: Rineka Cipta

Coombs, P. (1987). Cost analysis education- a tool for policy and planning. Washington: The World Bank

Creswell, J.W. (2010), Reserch design: pendekatan kualitatif, kuantitatif dan mixed. (terjemahan Ahmad Fawaid). California: @Sage Publication. (Buku asli diterbitkan tahun 2009)

Direktur Jendral Pendidikan Anak Usia Dini, Non Formal dan Informal. (2011). Petunjuk teknis penyelenggaraan paud berbasis taman pendidikan al-quran. Jakarta: Kementerian Pendidikan Nasional.

Fattah, N. (2009). Ekonomi dan pembiayaan pendidikan. Bandung: Remaja Rosdakarya

Ghozali, A. (2010). Ekonomi pendidikan. Jakarta: Lembaga penelitian UIN Syarif Hidayatullah

Gonzales J. \& Mena. (2011). Foundations of early childhood education. New York: Mc Graw Hill Company

Hallak, J. (1985). Dasar-dasar perencanaan pendidikan, (terjemahan Dr Harso). Jakarta: Bhatara Karya Aksara. (Buku Asli diterbitkan tahun 1969)

Jones, T.H. (1985). Introduction to school finance, technique and social policy. New York: MacMillan Publishing Co. 
Levin, H.M. \& Schwartz, H.L. (2006). Cost of early childhood care and education program. Background paper for EFA Global Monitoring Report 2007. Diambil pada tanggal 2 Desember 2013, dari http:// unesdoc. unesco.org_0014_00147. 147471e.pdf

Lima, C.M.F. (2011). The applicability of the principles of activity based costing system in a higher education institution. Economic and management research project: an international journal-ISSN: 21840309, p.57-65. Diambil pada tanggal 24 Desember 2013, dari http://webapps.fep.up.pt /oaij/index.php/EMRP.IJ/article.

Pitch.L. \& Edwards, O. (2003). Kindergarten study: full-day versus half-day program. Nevada: Clark and County School District. Diambil pada tanggal 2 Desember 2013, dari http://ccsd.net/resources/ful-daykindergarten-review-ofliterature.pdf.

Mowen, M.M. \& Hansen, D.R. (2000). Manajemen biaya: akutansi dan pengendalian. (diterjemahkan Penerbit Salemba Empat). Singapore: Thomson Learning Asia. (buku asli diterbitkan tahun 2000).

Morrison, G.S. (1988). Early childhood education today- fourth edition. Columbus: Merril Publishing Company.

Mulyadi. (2007). Activity based cost system. Yogyakarta: UPP STIM YKPN Yogyakarta

Mulyasa, E. (2011). Manajemen berbasis sekolah. Bandung: Alfabeta

Mulyono. (2010). Konsep pembiayaan pendidikan. Jogjakarta: Ar-Ruzz Media

Nurhadi, M.A.N. (2011). Dilema kebijakan pendanaan pendidikan. Yogyakarta: Nurhadi Center
Olubor, R. (2009). Private cost analysis of pre-school education in nigerian private schools. Kamla Raj: Journal Soc Sci, 19(2): 141-148. Diambil pada tanggal 2 Desember 2013, dari http:// krepublisher.com/journal/j ss.-19-2-141-2009-659.

Partini. (2010). Pengantar pendidikan anak usia dini. Yogyakarta: Grafindo Litera Media

Patmonodewo, S. (2003). Pendidikan anak prasekolah. Jakarta: PT. Rineka Cipta

Poston,W. (2011). School budgeting for hard times. United States of America: SAGE Company

Siregar,I. (2003). Studi biaya pendidikan madrasah ibtidaiyah. Jakarta: Puslitbang Pendidikan Agama dan Keagamaan

Sugiyono. (2013). Memahami penelitian kualitatif. Bandung: Alfabeta

Suhardan, D. (2012). Ekonomi dan pembiayaan pendidikan. Bandung: Alfabeta

Supriadi, D. (2010). Satuan biaya pendidikan dasar dan menengah. Bandung: PT. Rosda Karya

Turney, P.B.B. (Summer 1989). Activitybased costing: a tool for manufacturing excellence. Artikel 892.2A4, diambil pada tanggal 23 desember 2013, dari www.ame. org/sites/default/files/target_artic les/89Q2A4.pdf

Wibowo, A. (2012). Pendidikan karakter usia dini. Yogyakarta: Pustaka Pelajar

Woodhall, M. (1970). Cost benefits analysis on educational planning. Paris: United Nation Educational Scientific and Cultural Organization.

Vazakidis,A. , Karagianis,I. , Tsialta, A. (2010). Activity based costing in the public sector. Journal of social sciences 6 (3): 376-382, 2012. Diambil pada tanggal 24 Desember 2013, dari http://thescipub.com/pdf/ 10.3844 /jssp.2010.376.382. 